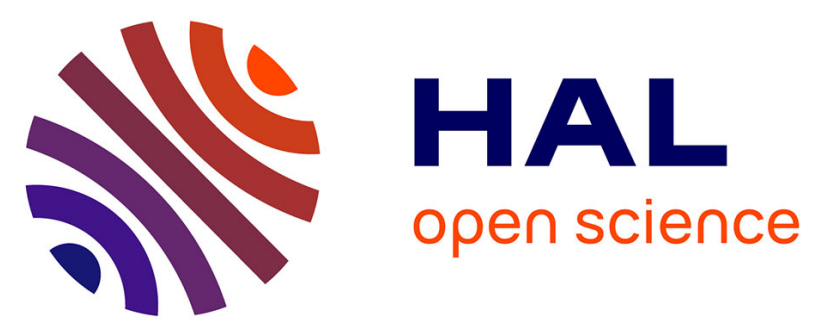

\title{
Alsinol, an arylamino alcohol derivative active against Plasmodium, Babesia, Trypanosoma, and Leishmania: past and new outcomes
}

Maria H. Arias, Miguel Quiliano, Sandra Bourgeade-Delmas, Isabelle Fabing, Isabelle Chantal, David Berthier, Cécile Minet, Véronique Eparvier, Jonathan Sorres, Didier Stien, et al.

\section{To cite this version:}

Maria H. Arias, Miguel Quiliano, Sandra Bourgeade-Delmas, Isabelle Fabing, Isabelle Chantal, et al.. Alsinol, an arylamino alcohol derivative active against Plasmodium, Babesia, Trypanosoma, and Leishmania: past and new outcomes. Parasitology Research, 2020, 119 (10), pp.3503-3515. 10.1007/s00436-020-06832-y . hal-02915989

\section{HAL Id: hal-02915989 \\ https://hal.science/hal-02915989}

Submitted on 5 Nov 2020

HAL is a multi-disciplinary open access archive for the deposit and dissemination of scientific research documents, whether they are published or not. The documents may come from teaching and research institutions in France or abroad, or from public or private research centers.
L'archive ouverte pluridisciplinaire HAL, est destinée au dépôt et à la diffusion de documents scientifiques de niveau recherche, publiés ou non, émanant des établissements d'enseignement et de recherche français ou étrangers, des laboratoires publics ou privés. 


\section{Alsinol, an arylamino alcohol derivative active \\ against Plasmodium, Babesia, Trypanosoma, and Leishmania.}

\section{Past and new outcomes}

Maria-Helena Arias ${ }^{1}$, Miguel Quiliano ${ }^{2}$, Sandra Bourgeade-Delmas ${ }^{3}$, Isabelle Fabing ${ }^{4}$, Isabelle Chantal ${ }^{5,6}$, David Berthier ${ }^{5,6}$, Cécile Minet ${ }^{5,6}$, Veronique Eparvier ${ }^{7}$, Jonathan Sorres ${ }^{7}$,

Didier Stien $^{8}$, Silvia Galiano ${ }^{9}$, Ignacio Aldana ${ }^{9}$, Alexis Valentin ${ }^{3}$, Giovanny Garavito ${ }^{1 *}$, Eric Deharo $^{3,10}$.

1. Universidad Nacional de Colombia, Sede Bogotá, Facultad de Ciencias, Departamento de Farmacia (DFUNC), Grupo de Investigación FaMeTra (Farmacología de la Medicina Tradicional y Popular); Carrera 30 45-03, Bogotá D.C. 111321, Colombia.

2. Universidad Peruana de Ciencias Aplicadas (UPC), Faculty of Health Sciences, Centre for Research and Innovation, 15023, Lima, Perú.

3. UMR 152 PHARMA-DEV, Institut de Recherche pour le Développement IRD, Université de Toulouse UPS, France.

4. Laboratoire de Synthèse et Physicochimie de Molécules d'Intérêt Biologique (SPCMIB), Centre National de la Recherche Scientifique (CNRS), 31062, Toulouse, Cedex 09 France.

5. CIRAD, UMR INTERTRYP, F-34398 Montpellier, France.

6. INTERTRYP, Université Montpellier, CIRAD, IRD, Montpellier, France.

7. CNRS, Institut de Chimie des Substances Naturelles, UPR 2301, Université ParisSaclay, 91198 Gif-sur-Yvette, France.

8. Sorbonne Université, CNRS, Laboratoire de Biodiversité et Biotechnologie Microbienne, LBBM, Observatoire Océanologique, 66650, Banyuls-sur-mer, France.

9. Universidad de Navarra, Facultad de Farmacia y Nutrición, Departamento de Química Orgánica y Farmacéutica, Campus Universitario, 31008 Pamplona Spain. 
10. Institut de Recherche pour le Développement, Représentation IRD Ban Nasay, Saysettha District. P.O. Box 5992, Vientiane, Lao PDR.

Running title: Alsinol, a new molecule active against protozoan infections.

Corresponding author: Carrera 30 45-03, Bogotá D.C. 111321, Colombia. Tel: +57

3003217098. Email: ggaravitoc@unal.edu.co

\begin{abstract}
Background: Malaria, babesiosis, trypanosomosis, and leishmaniasis are among the most life-threating parasites, but the range of drugs to treat them is limited. It is then urgent to have an effective, safe drug with a large spectrum of activity at a low cost.
\end{abstract}

Methods: For this purpose, an aryl amino alcohol derivative called Alsinol was resynthesized, screened in silico and tested against Plasmodium, Babesia, Trypanosoma, and Leishmania.

Results: Alsinol was easy to synthesize, following the Lipinski and Ghose rules calculated in silico. It had schizontocidal activity against $P$. falciparum and was able to inhibit gametocytogenesis, being particularly active against late gametocytes in vitro. On malariainfected mice, it showed a dose-dependent activity similar to chloroquine. It was also as active as reference compounds against $B$. divergens, and against promastigotes and amastigotes stages of Leishmania in vitro. It also inhibited the in vitro growth of two African animal strains of Trypanosoma but was ineffective in vivo in our experimental conditions. It showed acceptable toxicity in J774A1 and Vero cells models.

Conclusion: Alsinol is inexpensive to produce, has a large spectrum of activity with an interesting toxicity index. Nevertheless, crucial challenges remain to be faced: the description of a suitable clinical formulation and the determination of the safety margin in preclinical models.

Keywords: Antiprotozoan; Alsinol, Babesia; Cytotoxicity; Leishmania; Malaria; Oral administration; Plasmodium falciparum gametocytes; Trypanosoma. 


\section{Introduction}

After almost 70 years of extensive campaigns of insecticides and utilization of antimalarials, Plasmodium is still a cause of great concern for public health. Although artemisinin and its derivatives represent major progress in the therapeutic arsenal, cases of resistance have been already registered. ${ }^{1,2}$ Consequently, the search for alternatives is still on the agenda of Medicines for Malaria Venture, in particular drugs capable of eliminating sexual forms, thus blocking the disease transmission cycle. ${ }^{3}$

Advances in knowledge of the genome and parasite metabolism have established that there are biochemical and physiological processes common to different parasites. ${ }^{4,5}$ Unlike eukaryotes, the majority of protozoan parasites require essential salvage pathways for purine synthesis due to their involvement in the process of replication. Examples of these are the pathways involving the enzyme adenine phosphoribosyl transferase, which use adenine as a specific substrate, and the pathway involving hypoxanthine, guanine, phosphoribosyl transferase, which uses hypoxanthine and guanine as substrates.

The first one is a common pathway for P. falciparum, B. divergens, T. brucei, T. congolense, T. cruzi and T. vivax, while the latter is for B. divergens, T. brucei and T. cruzi. $^{4}$ DNA topoisomerases, involved in DNA replication, transcription, recombination and repair processes are also potential targets e.g., camptothecin, acts as a class I inhibitor, producing the formation of covalent enzyme-DNA complexes and causing cellular apoptosis of $P$. falciparum and T. brucei. ${ }^{5}$ Consequently, drugs targeting one or more biochemical processes 
common to different protozoa could be the "magic bullet" against different species respecting the host who takes specific biochemical pathways.

Synthetic compounds can be designed in such a way that they can be cheap, effective (at least in theory) and target some specific metabolic pathways of parasites, i.e., being potentially less toxic against the host.

In an attempt to find a new antimalarial with such characteristics, a series of 1-aryl-3substituted propanol derivatives (APDs) were designed, synthesized and evaluated previously by us. $^{6-9}$

Among the most active APDs against Plasmodium in vitro, one caught our attention: the 1-(4Fluoro-phenyl)-3-[1-(4-nitro-2-trifluoromethyl-phenyl)-piperidin-4-ylamino]-propan-1-ol

hydrochloride also well-known as Alsinol. We describe herein its synthesis pathway, chemical characteristics, in silico screening, activity against different laboratory models of Plasmodium growth and extend our study to Babesia, Trypanosoma, and Leishmania that are sensitive to aryl amino alcohol.

\section{Materials and methods}

\section{Chemistry}

Synthesis (Figure.1)<smiles>CC(C)(C)OC(=O)NC1CCN(c2ccc(N3CCC(NC4CCN(c5ccc([N+](=O)[O-])cc5C(F)(F)F)CC4)CC3)c(C(F)(F)F)c2)CC1</smiles><smiles>C=CC(=O)c1ccc(F)cc1</smiles> 
Figure 1: Synthesis of Alsinol 1-(4-Fluoro-phenyl)-3-[1-(4-nitro-2-trifluoromethyl-phenyl)piperidin-4-ylamino]-propan-1-ol and chemical structure.

The method used for synthesizing Alsinol is presented in Figure 1. The synthetic method has been published previously. ${ }^{6,8,10}$ Non-commercially available arylamine was synthesized using BOC-amine and 2-fluoro-4-nitrobenzotrifluoride by an $\mathrm{Ar}-\mathrm{S}_{\mathrm{N}}$ ' reaction via Meisenheimer complex and subsequent removal of the BOC-group with $\mathrm{HCl}$ and acetic acid. The methyl ketone 4'-fluoroacetophenone was commercially available. The ketone intermediate was prepared by condensation of the methyl ketone 4'-fluoroacetophenone with the aryl amine via Mannich reaction. The hydroxyl derivative ( $\gamma$-amino alcohols) was obtained by reduction of the corresponding carbonyl group with $\mathrm{NaBH}_{4}$ in methanol.

Separation of enantiomers (Figure 2)
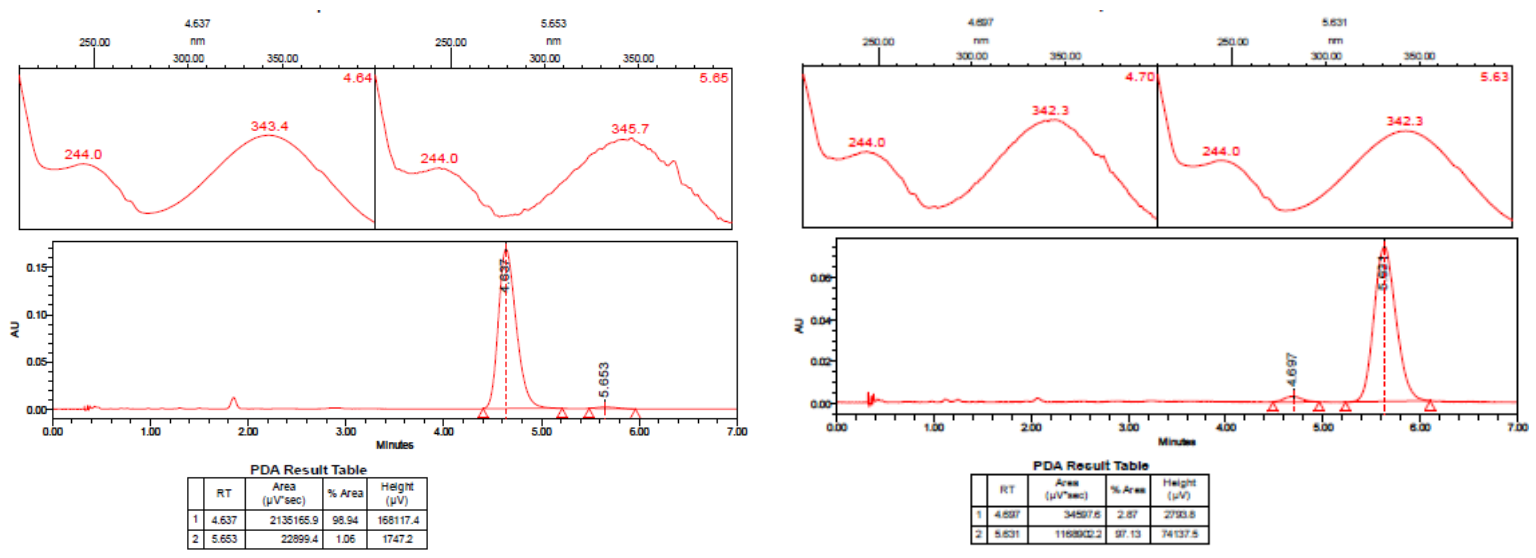

Figure 2: separation of Alsinol enantiomers, the first peak is around $99 \%$ enantiopure (left) and the second around $98 \%$ (right).

The synthesis of Alsinol leads to 2 enantiomers that have been separated at the Laboratoire de Synthèse et Physicochimie de Molécules d'Intérêt Biologique, Toulouse, France.

The separation was conducted on chiral column Chiralpak IC column packed with $3 \mu \mathrm{m}$ silica particles immobilized with cellulose tris (3,5-dichlorophenylcarbamate). Chiral separations 
were carried out on an Acquity $\mathrm{UPC}^{2}$ system from Waters for control analysis and on Prep80q system from Waters for preparative enantioseparations. The best elution conditions were with $20 \%$ of isopropanol $+0.1 \%$ of DEA as an additive in a $\mathrm{CO}_{2}$ mobile phase. The analytical flow rate was $3.5 \mathrm{ml} / \mathrm{min}$. The outlet pressure was $130 \mathrm{bar}$ on $\mathrm{UPC}^{2}$ equipment from Waters. The injector valve was supplied with a $10 \mu \mathrm{L}$ loop. The columns were thermostated by an oven regulated at $40^{\circ} \mathrm{C}$. The automatic back pressure regulator was maintained at 130 bar. The PDA detector was carried out at $342 \mathrm{~nm}$. Injection volumes were $10 \mu \mathrm{l}$ for analytical scale.

\section{In silico study}

Alsinol was introduced in the Lilly Open Innovation Drug Discovery platform (OIDD). ${ }^{11}$ The molecular structure of Alsinol was processed following the Lilly Medicinal Chemistry Rules comprising a set of 275 rules, developed over 18 years, to identify compounds that may interfere with biological assays, allowing their removal from screening sets. On Lilly, the computational platform molecular structure of Alsinol was converted to a set of descriptors or "fingerprints" and compared to the full set of all fingerprints previously submitted to the OIDD program. Lilly MedChem Rules are used to identify and discard pharmaceutically undesirable motifs, ${ }^{12}$ as is done at many pharmaceutical companies. ${ }^{13}$

\section{Bioactivities}

\section{Chemicals}

Chloroquine diphosphate (CQ), primaquine (PQ), doxorubicin, miltefosine, amphotericin $\mathrm{B}$, hypoxanthine and $\mathrm{N}$-acetyl-D-glucosamine were acquired from Sigma ${ }^{\circledR}$, Imodocarbe dipropionate $\left(\right.$ Carbesia $\left.^{\circledR}\right)$, was purchased from MSD Animal Health (France), Diminazene aceturate $\left(\right.$ Veriben ${ }^{\circledR}$ ) was acquired from Ceva-Libourne, France and SYBR I was from INVITROGEN $^{\circledR}$. Hypoxanthine was prepared as a stock solution at $10 \mathrm{mM}$. SYBR I was prepared as a stock solution in DMSO at $100 \mathrm{X}$ concentration which was stored at $-20^{\circ} \mathrm{C}$ 
protected from light and thawed immediately before use. The lysis buffer consists of a solution of Tris $(20 \mathrm{mM})$, EDTA $(5 \mathrm{mM})$, saponin $(0.008 \%[\mathrm{w} / \mathrm{v}])$ and Triton X-100 (0.08\% [v/v]), which was previously prepared, adjusted to $\mathrm{pH} 7.5$ and stored at $4{ }^{\circ} \mathrm{C}$.

\section{Parasites and cells}

The W2 strain of P. falciparum and Babesia divergens Rouen (1987), Leishmania infantum, Vero cells, HepG-2 (Human hepatocellular carcinoma cells) and the Macrophage-like cell line J774A.1 were obtained from the University Paul Sabatier Toulouse III (France), Plasmodium berghei (ANKA), was obtained from the Institute of Immunology of the University of the Valley, San Fernando; Trypanosoma congolense IL3000, Trypanosoma brucei brucei Antat 1.1 and cultivation protocol were kindly provided by Dr. Loïc Rivière and Nicolas Plazolles (UMR CNRS-5234, University of Bordeaux). Trypanosoma congolense IL1180 was obtained from Intertryp unit and International Research Center on Livestock Development in the Subhumid Zone of Burkina Faso.

\section{In vitro studies}

Antiplasmodial activity against sexual stage of Plasmodium

\section{Production and maturation of gametocytes}

The W2 strain (Indochina strain, chloroquine-resistant) of $P$. falciparum was kept in continuous culture in the laboratory, according to Trager and Jensen. ${ }^{14}$ The parasitized red blood cells (pRBCs) were grown in $25 \mathrm{ml}$ flasks (Corning Costar Corporation ${ }^{\circledR}$, USA), containing $8.5 \mathrm{ml}$ of RPMI 1640 medium, $0.7 \mathrm{ml}$ of Human Serum, $0.1 \mathrm{ml}$ L-glutamine and 400 $\mathrm{ml}$ of parasitized blood (hematocrit $=4 \%$ ). Parasitemia remained between 0.5 and $4 \%$ (about 2\%). Adjustments were made with non-parasitized red blood cells (Red blood cells and human serum were obtained from EFS, Toulouse, France). Cultures were incubated at $37^{\circ} \mathrm{C}$ in an atmosphere of $5 \% \mathrm{CO}_{2}$ and a humidity of about $90 \%$. The medium was renewed every day and a microscopic control $(1,000 \mathrm{X})$ of the parasitemia was carried out employing a blood smear fixed with methanol and colored with Giemsa. ${ }^{15}$ The culture was synchronized with 5\% 
sorbitol. The production and maturation of gametocytes in vitro were performed according to Ifediba \& Vanderberg, ${ }^{16}$ Chevalley et al. ${ }^{17}$ and Amoah et al., ${ }^{18}$ with minor modifications.

Gametocytes viability assay

The test was carried out with serial dilutions of Alsinol $(0.4$ to $420 \mu \mathrm{M})$ in a 12 well plate on D+14 gameto stage, parasitemia $0.2 \%$, hematocrit $25 \%$ and $20 \%$ Human serum, incubated for $48 \mathrm{~h}$ at $37^{\circ} \mathrm{C}$, in $5 \% \mathrm{O}_{2}, 5 \% \mathrm{CO}_{2}$, and $90 \% \mathrm{~N}_{2}$. Primaquine $(22 \mu \mathrm{M})$ was used as a control. The gametocytaemia corresponding to each dilution was evaluated by microscopy, and the $\mathrm{IC}_{50}$ was determined by a regression model.

\section{Gametocytogenesis inhibition test}

Production and maturation of gametocytes were followed up until D+8. The test was carried out as for a Gametocyte viability assay. Gametocytogenesis was evaluated morphologically using Giemsa-stained blood films corresponding to each dilution, and the $\mathrm{IC}_{50}$ was determined using the regression model.

\section{Antibabesial activity}

Babesia divergens Rouen 1987, was cultivated according to Gorenflot et al., ${ }^{19}$ with some modifications. Red blood cells parasitized were grown in $25 \mathrm{ml}$ flasks (Corning Costar Corporation $^{\circledR}$, USA), with $4.5 \mathrm{ml}$ of RPMI 1640 medium, $0.5 \mathrm{ml}$ of human serum, and $250 \mathrm{ml}$ of parasitized blood (5\% hematocrit) at $37^{\circ} \mathrm{C}$ in $5 \% \mathrm{CO}_{2}$. The medium was renewed every day and a microscopic control $(1,000 \mathrm{X})$ of the parasitemia was determined on Giemsa stained smears. $^{15}$

The sensitivity to the drug was determined on $1.2 \%$ parasitaemia, with Alsinol concentrations ranging from 0.21 to $420 \mu \mathrm{M}$. Imidocarb dipropionate was used as a positive control. The plates were incubated for $24 \mathrm{~h}$ at $37^{\circ} \mathrm{C}$ in a $\mathrm{CO}_{2}$ atmosphere $(5 \%)$; the parasitemias corresponding to each dilution were evaluated by fluorometry ${ }^{20}$, and the $\mathrm{IC}_{50}$ was determined by a regression model.

Anti-trypanosoma activity

Trypanosoma congolense IL3000 bloodstream forms and Trypanosoma brucei brucei Antat 
1.1 bloodstream forms were cultured with $100 \mu \mathrm{l}$ in complete MEM and IMDM culture medium respectively at $25 \times 10^{3}$ cells in 96 -well plates for $24 \mathrm{~h}$ at $34^{\circ} \mathrm{C}$ and $37^{\circ} \mathrm{C}$ respectively with $5 \% \mathrm{CO}_{2}$. Alsinol assays were performed with $150 \mu \mathrm{l}$ of Alsinol solution at $10 \mu \mathrm{g} / \mathrm{ml}$ in 0.1\% DMSO. Three controls were included: a trypanocidal control with $150 \mu$ l of Diminazene aceturate at $1.5 \mu \mathrm{g} / \mathrm{ml}$, a negative control without a drug and a $0.1 \%$ DMSO control. All assays were performed three times in triplicate. After $24 \mathrm{~h}$, parasite proliferation was determined using the Malassez cell numeration.

\section{Anti-leishmania activity}

Parasites of Leishmania infantum transfected with luciferase gene were maintained at $24^{\circ} \mathrm{C}$ in RPMI 1640 medium containing 10\% heat-inactivated fetal bovine serum. Parasites were harvested by centrifugation (900 g, $10 \mathrm{~min}$ ) and washed two times in $\mathrm{NaCl} 0,9 \%$, resuspended in medium and distributed in a 24-well plate. For the determination of anti promastigote activity, Alsinol was incorporated in the medium at growing concentrations. The Luciferase enzyme present in Leishmania infantum transfected with luciferase gene converts a substrate D-luciferase + ATP to a reaction product (oxyluciferin, excited state) that emits photons which are measured with a luminometer; therefore the amount of ATP is directly proportional to the number of live parasites present in each well.

\section{Toxicity}

The assay was adapted from Cachet et al. ${ }^{21}$ using normal monkey kidney cells (Vero cells) under the similar P. falciparum culture conditions, except that human serum was changed to $10 \%$ fetal calf serum. After the addition of Alsinol at increasing concentrations, cell growth was measured by $[3 \mathrm{H}]$-hypoxanthine incorporation after a $48 \mathrm{~h}$ incubation period and then compared with a control sample. Doxorubicin and amphotericin B were used as controls.

Macrophages murine J774 A.1 were maintained at $37^{\circ} \mathrm{C}$ in RPMI 1640 culture medium supplemented with $10 \%$ heat-inactivated fetal bovine serum; cultures were allowed to $70-80 \%$ confluent and cells were gently scraped. Cells were diluted in culture medium to $10^{6}$ cells $/ \mathrm{ml}$ final concentrations and distributed into a 24 -well plate and incubated for $24 \mathrm{~h}$. The activity of 
Alsinol was determined by an MTT colorimetric assay (Eon Microplate Spectrophotometer Gen5 $5^{\mathrm{TM}}$ v 2.0 at 570nm). Miltefosine, doxorubicin and amphotericin B were used as control drugs.

Alsinol was also tested on HepG-2 cells. Chloroquine was used as a control drug.

\section{In vivo studies}

\section{Antimalarial}

Studies were carried out in accordance with Colombian legislation on the use and care of laboratory animals $\left(\mathrm{N}^{\circ}\right.$ 008430) and approved by the Faculty of Science Ethics Committee (Dec 04-2017). Swiss mice (5 to 6 weeks-old) were obtained from the Bioterium Pharmacy Department, Universidad Nacional de Colombia and housed at $18^{\circ} \mathrm{C}$ in a $12 \mathrm{~h} \mathrm{light/dark} \mathrm{cycle,}$ with free access to commercial food pellets and water. Plasmodium berghei ANKA parasites were maintained by weekly passage of infected blood to the Swiss mice.

Blood schizontocidal activity on $P$. berghei was determined through a variation of the experimental design of the 4-day test of Peters \& Robinson, ${ }^{22}$ adapted by Garavito. ${ }^{23}$ Compounds were tested by oral route to establish $\mathrm{ED}_{50}$ and $\mathrm{ED}_{90}$ values. ${ }^{24}$ Mice were randomly assigned into groups of five and were infected intraperitoneally with $0.1 \mathrm{ml}$ containing $10^{7}$ parasitized cells, from a donor mouse (day 0). After two hours of infection and at the same time for four consecutive days (D0 to D+3), the mice were then orally dosed with Alsinol (dose-ranging 6.25-50 mg/kg/day). ${ }^{8}$ Chloroquine diphosphate (CQ), dose-ranging 1.5$12 \mathrm{mg} / \mathrm{kg} /$ day, was used as a control drug. A group received the vehicle of treatments $(90 \%$ DMSO/water solution). Survival of the mice was checked daily and the percentage of parasitized erythrocytes was determined on D+4, with SYBR green I as described previously. ${ }^{25}$ The percentage of inhibition of parasitemia was calculated and $\mathrm{ED}_{50}$ and $\mathrm{ED}_{90}$ were determined by a regression model.

\section{Trypanocidal}


All procedures for animal maintenance and experimental procedures were approved by the Languedoc-Roussillon regional ethics committee (French CE-LR \#36) in the authorized Project using animals for scientific purposes \#C34-172-20. Eight groups of $5 \mathrm{Balb} / \mathrm{C}$ mice, aged 6 weeks, were used for in vivo assays. Four assays groups were designed with an infected group, infected/Alsinol group, infected/Diminazene aceturate group, and infected/DMSO group. Five control groups were included with negative control, infected control, DMSO control, Alsinol control and Diminazene aceturate control.

Mice infection was performed by intraperitoneal (IP) injection with $10^{4}$ of Trypanosoma congolense IL1180 diluted in $1 \%$ salt glucose solution. The weight of the mice and their anemia (PCV packed cell volume) estimation were measured before infection, during infection and at the end of the experimental procedure. As soon as parasites were detectable under microscope observation, the mice were treated by IP injection with $200 \mu 1$ of Alsinol at $2 \mathrm{mg} / \mathrm{ml}$ or with Diminazene aceturate at $3.5 \mathrm{mg} / \mathrm{kg}$ or with $4 \%$ DMSO. The same treatment was performed for control groups. Parasitemia was determined daily by blood collection from the tails of the mice by field method estimation; survival at D+9 was determined. ${ }^{26}$

\section{Results}

\section{Chemistry}

\section{Structure}

The synthesized final Alsinol was chemically characterized by melting point (mp) and proton and carbon nuclear magnetic resonance $\left({ }^{1} \mathrm{H}\right.$ NMR and ${ }^{13} \mathrm{C}$ NMR $)$ spectra as well as by elemental microanalysis: Yield: $11 \%, \mathrm{mp} 185-187{ }^{\circ} \mathrm{C},{ }^{1} \mathrm{H}$ NMR (400 MHz, DMSO-d $\left.{ }_{6}\right) \delta$ : 8.37 (brs, 2H), $7.50(\mathrm{~d}, 1 \mathrm{H}, J=8.0 \mathrm{~Hz}), 7.36(\mathrm{br} \mathrm{s}, 2 \mathrm{H}), 7.13(\mathrm{t}, 2 \mathrm{H}, J=8.1 \mathrm{~Hz}), 5.61(\mathrm{~s}, 1 \mathrm{H})$; $4.69(\mathrm{t}, 1 \mathrm{H}, J=9.0 \mathrm{~Hz}), 3.20-3.30(\mathrm{~m}, 2 \mathrm{H}), 2.95(\mathrm{t}, 2 \mathrm{H}, J=12.1 \mathrm{~Hz}), 2.63-2.64(\mathrm{~m}, 2 \mathrm{H}), 2.58$ (br s, $1 \mathrm{H}), 1.90(\mathrm{~d}, 2 \mathrm{H}, J=11.0 \mathrm{~Hz}), 1.70($ br s, $2 \mathrm{H}), 1.38$ (br s, 2H) ppm. ${ }^{13} \mathrm{C}$ NMR (DMSO$\left.\mathrm{d}_{6}, 100 \mathrm{MHz}\right) \delta: 163.06 ; 160.66 ; 157.70 ; 143.19(\mathrm{~d}, J=2.7 \mathrm{~Hz}) ; 141.73 ; 129.21 ; 128.34(2 \mathrm{C}$, 
$\mathrm{d}, J=8.0 \mathrm{~Hz}) ; 124.98(\mathrm{q}, J=6.0 \mathrm{~Hz}) ; 123.88 ; 122.82 ; 115.49(2 \mathrm{C}, \mathrm{d}, J=21.1 \mathrm{~Hz}) ; 71.59$;

54.24; 52.08 (2C); 44.00; 35.62; 32.34 (2C) ppm. Anal. Calcd for $\mathrm{C}_{21} \mathrm{H}_{23} \mathrm{~N}_{3} \mathrm{~F}_{4} \mathrm{O}_{3}$.HCl: C, 52.51\%; H, 5.03\%; N, 8.80\%; Found: C, 52.13\%; H, 4.91\%; N, 8.49\%.

\section{In silico}

Physicochemical properties (ADME profile).

Chemical descriptors and physico-chemical properties of Alsinol are reported in Table 1.

Table 1: Physical chemical properties of Alsinol and chloroquine, Lipinski's rules ${ }^{27}$ and Ghose "qualifying range"28.

\begin{tabular}{lccc}
\hline \multicolumn{1}{c}{ Properties } & $\begin{array}{c}\text { Lipinski's rule } \\
\text { (Ghose's rule) }\end{array}$ & Alsinol & Chloroquine \\
\hline Molecular weight & $>500(160-480)$ & 441 & 320 \\
CLOGP & $<5(-0.4-5.6)$ & 3.84 & 4.63 \\
NH- or OH- bond & $\leq 5$ & 2 & 1 \\
donors & $\leq 10$ & 6 & 3 \\
H- bond acceptors & $(20-70)$ & 54 & 48 \\
Total number of atoms & $\leq 10$ & 7 & 8 \\
n-ROTB & $<140 \AA^{2}$ & 81.3 & 28.2 \\
Polar surface area & $(\leq 1)$ & 0 & 0 \\
\hline Rule's violations & & 81 & 99 \\
\hline$\%$ ABS: & & 0.39 & 0.21 \\
Hydrophilicity & & 1.51 & 0.96 \\
CLOGD@PH=7.4 & & 14.4 & 10.18 \\
Acidic PKA & 9.78 & 8.38 \\
Basic PKA & & 31 & \\
Heavy Atoms & & 3 & 2 \\
Rings & & 5 & 4 \\
Elements & & 0 & 1 \\
Aromatic hetero atoms & & 0.3871 & \\
Aromatic Density & & 0.4194 & \\
Fraction Spinach & & 2 & 2 \\
Aromatic rings & & 1 & 0 \\
Aliphatic rings & & 9 & \\
CSP3 & & 0.2903 & \\
Fraction CSP3 & & & \\
\hline
\end{tabular}

\%ABS: human intestinal absorption, calculated by: \%ABS=109-(0.345 x Topological Polar Surface Area). Hydrophilicity: $\log \mathrm{D}(\mathrm{pH}: 7.4) / \log \mathrm{P}$. 
Alsinol passed the first in silico screen of Lilly OIDD. This means that it was considered that it does not generate interference with assay measurements (fluorescence, absorbance, quenching), it does not have activities that damage proteins (oxidizers, detergents), has no instability (e.g., latent aldehydes), does not lack druggability (e.g., compounds lacking both oxygen and nitrogen), it has an acceptable index of biological promiscuity. ${ }^{12}$

\section{Bioactivities}

\section{In vitro}

In vitro results against Plasmodium, Babesia, Trypanosoma and Leishmania are displayed in Table 2. Alsinol showed schizontocidal activity against $P$. falciparum in culture ranging from around 0.48 on FCR-3 and D6 strains to 1.05 on the C235 strain (previously reported data ${ }^{6,8}$ ). Against late stage gametocytes of $P$. falciparum, Alsinol inhibits parasites preferentially in their mature sexual stage following a dose-dependent scheme (Figure 3). Cultures treated with Alsinol and primaquine produced fewer gametocytes than the control $(\mathrm{p}<0.05$, Tukey posthoc test). The active control drug (PQ), at $22 \mu \mathrm{M}$, generated a total inhibition of gametocytogenesis.

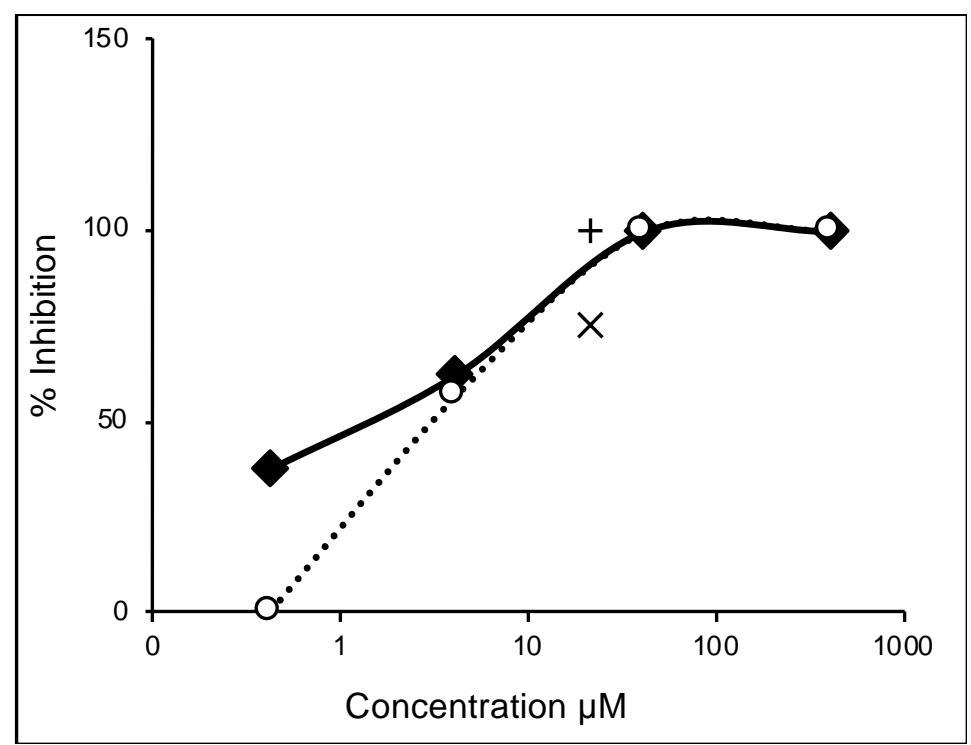


Figure 3. Inhibition of sexual stages of P. Falciparum W2 by Alsinol.

Gametocytogenesis inhibition (dotted line) and gametocide effect (plain line). The effect of primaquine is visualised with crosses.

Against $B$. divergens, Alsinol shows concentration-dependent inhibition (Figure 4), with $\mathrm{IC}_{50}$ being an order of magnitude greater than that of the active control drug, Table 2. Cultures treated with Alsinol (52 and $26 \mu \mathrm{M})$ and ID $(200,20$ and $2 \mu \mathrm{M})$ produced fewer parasites than the control untreated cultures $(\mathrm{p}<0.05$ in each case, Tukey post-hoc test).

Alsinol inhibited $100 \%$ of Trypanosoma b. brucei and Trypanosoma congolense growth at $21 \mu \mathrm{M}$.

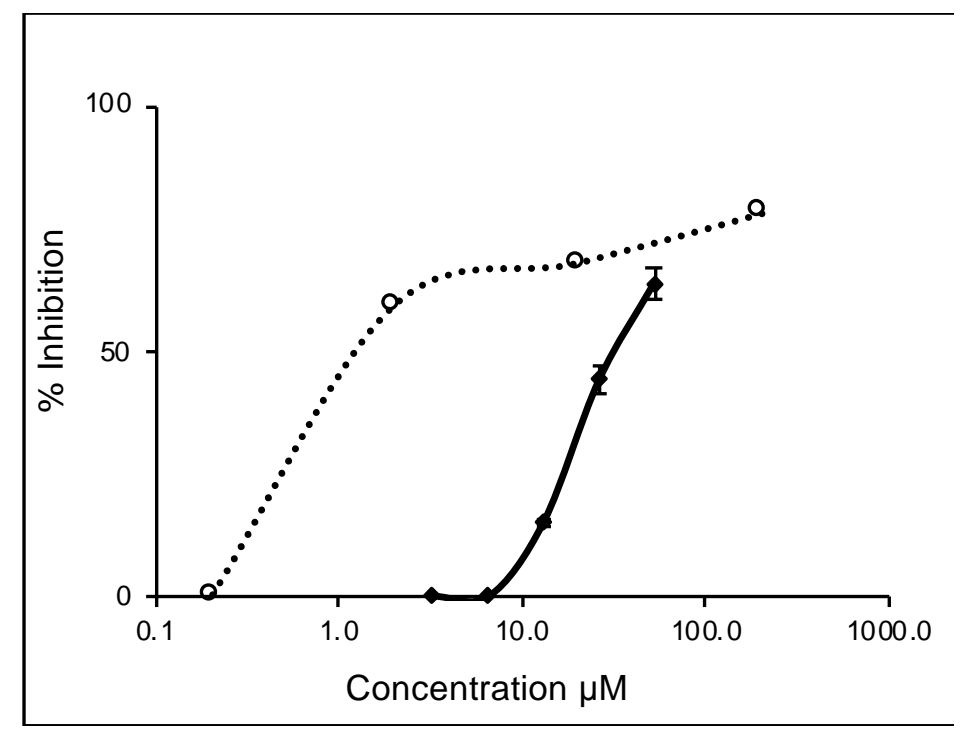

Figure 4. Growth inhibition of Babesia divergens (Alsinol plain line, Imidocarb propionate dotted line).

Alsinol was also active against Leishmania infantum promastigote and amastigote forms inhibiting $50 \%$ of parasite growth at around 2 and $8 \mu \mathrm{M}$ respectively.

The cytotoxicity of Alsinol was also determined on Vero cells, macrophage-like murine cells J774A.1, and on Hep-G2 cells. The $\mathrm{CC}_{50}$ was $30 \mu \mathrm{M}$ on Vero cells, 8.2 on J774 and 10.4 on Hep-G2. 
Table 2. In vitro and in vivo bioactivity of Alsinol, Chloroquine, Primaquine, Imidocarb, Diminazene aceturate, Miltefosine, Amphotericin B and doxorubicine.

\begin{tabular}{|c|c|c|c|c|c|c|c|c|}
\hline Assay & $\mathbf{A S N}$ & PQ & $\mathbf{C Q}$ & ID & DA & MIL & AmphoB & Doxo \\
\hline \multicolumn{9}{|c|}{ IN VITRO $\left(\mathrm{IC}_{50}\right.$ or $\left.\mathrm{CC}_{50} \mu \mathrm{M}\right)$} \\
\hline $\begin{array}{l}\text { Gametocyte } \\
\text { viability }\end{array}$ & 1.23 & $75 \% *$ & & & & & & \\
\hline $\begin{array}{l}\text { P. falciparum } \mathrm{W} 2 \\
\text { Gametocytogenesis } \\
\text { inhibition } \\
\text { P. falciparum } \mathrm{W} 2\end{array}$ & 3.75 & $100 \% *$ & & & & & & \\
\hline $\begin{array}{l}\text { Antibabesial effect } \\
\text { B. divergens }\end{array}$ & 34.0 & & & 3.8 & & & & \\
\hline \multicolumn{9}{|l|}{ Trypanocid effect } \\
\hline T. brucei brucei & $100 \% * *$ & & & & & & & \\
\hline T. congolense & $100 \% * *$ & & & & & & & \\
\hline \multicolumn{9}{|l|}{$\begin{array}{l}\text { Leishmanicidal } \\
\text { effect }\end{array}$} \\
\hline $\begin{array}{l}\text { L. infantum } \\
\text { Promastigots }\end{array}$ & 1.99 & & & & & 8.83 & 0.03 & \\
\hline L. infantum & & & & & & & & \\
\hline $\begin{array}{l}\text { Intramacrophagic } \\
\text { amastigots }\end{array}$ & 8.25 & & & & & 4.17 & 0.06 & \\
\hline \multicolumn{9}{|l|}{ Toxicity } \\
\hline Vero cells & 30.2 & & & & & & 6.4 & 6.4 \\
\hline HepG-2 & 10.4 & & 137 & & & & & \\
\hline J774A.1 & 8.25 & & & & & $>40$ & 2.47 & 0.06 \\
\hline \multicolumn{9}{|c|}{$\boldsymbol{I N} \boldsymbol{V I V O}\left(\mathrm{ED}_{50} \mathrm{mg} / \mathrm{Kg} /\right.$ day $)$} \\
\hline P. berghei & 17.4 & & 2.4 & & & & & \\
\hline T. congolense & Inactive & & & & $\begin{array}{l}80 \% \\
\text { urvival }\end{array}$ & & & \\
\hline
\end{tabular}


ASN: Alsinol, CQ: chloroquine, PQ: Primaquine, ID: Imidocarb, DA: Diminazene aceturate, MIL: Miltefosine, AmphoB: amphotericin B, Doxo: doxorubicine. IC $_{50}$ Concentration inhibiting $50 \%$ of parasite growth. $\mathrm{IC}_{90}$ Concentration inhibiting $90 \%$ of parasite growth. $\mathrm{CC}_{50}$ Concentration killing $50 \%$ of cells. $\mathrm{ED}_{50}$ Dose inhibiting $50 \%$ of parasite in vivo. $\mathrm{ED}_{90}$ Dose inhibiting $90 \%$ of the parasite in vivo. $* \%$ Inhibition at $22 \mu \mathrm{M} . * * \%$ Inhibition at $21 \mu \mathrm{M}$.

\section{In vivo}

Plasmodium infected animals treated with Alsinol (50 and $25 \mathrm{mg} / \mathrm{kg} / \mathrm{day}$ ) and CQ (12.6 and 3 $\mathrm{mg} / \mathrm{kg} /$ day) showed fewer parasites than untreated animals $(\mathrm{p}<0.05$ in each case, Tukey posthoc test) see Table 2 and Figure 5. Chloroquine had an effective doses $50\left(\mathrm{ED}_{50}\right)$ of 2.4 $\mathrm{mg} / \mathrm{kg} /$ day, consistent with the $\mathrm{ED}_{50}$ of $2.2 \mathrm{mg} / \mathrm{kg} /$ day and $2.3 \mathrm{mg} / \mathrm{kg} /$ day previously reported by our team, ${ }^{25,29}$ while Alsinol exhibited $\mathrm{ED}_{50}=17.4$ and $\mathrm{ED}_{90}=48 \mathrm{mg} / \mathrm{Kg} / \mathrm{day}$.

Against Trypanosoma congolense IL1180 (reference strain for experimental infection as it is less virulent than IL3000 enabling the infection to be monitored). Alsinol did not show activity in our model.

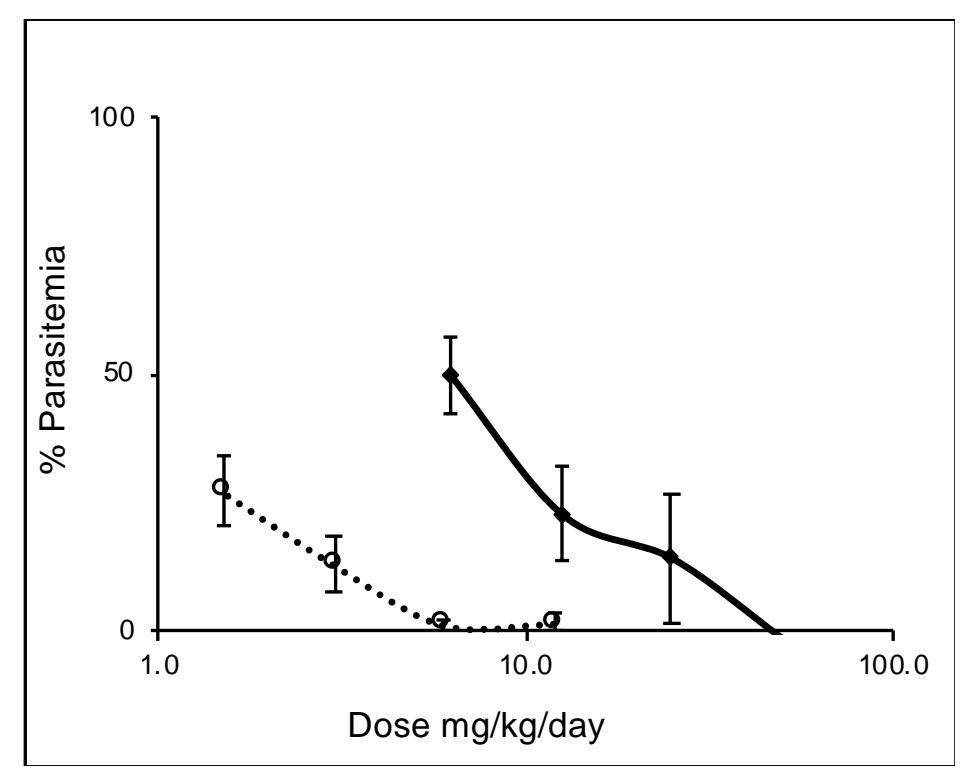

Figure 5. Alsinol antimalarial activity against $P$. berghei ANKA (Alsinol plain line, Chloroquine dotted line). 


\section{Discussion}

Vector-transmitted infectious diseases are a serious problem for human and animal health in tropical and subtropical regions of the world, affecting more than 500 million people, accounting for $16 \%$ of all communicable human diseases. In developed countries, their morbidity and mortality are increasing as a consequence of human migration, changes in the geographical distribution of vectors and the emergence of resistance to infectious agents. ${ }^{30-33}$ The control of parasitic diseases is essential to achieve several of the United Nations Sustainable Development Goals. $^{34}$

In the parasitic disease register, malaria is claimed to be responsible for more than 200 million cases and almost 500,000 deaths, with nearly half of the world's population at risk. Although the overall downward trend has undoubtedly stabilized and, in some areas, a decrease is becoming evident, according to $\mathrm{WHO}^{35}$, the fight against malaria still requires increased funding for control programs, greater access to effective interventions and investment in research and development of new tools.

In recent years, strategies to optimize existing antimalarial therapies focused on the use of combination therapies, the reuse of drugs in other indications and/or the use of natural products. ${ }^{33,36-39}$ In parallel, chemists all around the world still continue with the synthesis of potentially effective drugs structurally similar to existing drugs. This is what our team did by way of exploring the structure-activity relationship of $\gamma$-aminoalcohols and more specifically, the 1-aryl-3-substituted derivatives of propanol. ${ }^{6-9}$ The in vivo screening of the most promising compounds against $P$. berghei rodent malaria, revealed that the central amine influences the activity as seen with aminopiperidine analogues that are more active than piperazine analogues. Although compound "22" (Table 3) showed an excellent reduction of parasitemia, it had low in vitro selectivity index $(\mathrm{SI}=37)$ and was discarded. Then, Alsinol was selected to be studied further. 
Table 3. In vivo antimalarial efficacy of selected compounds in P. berghei-infected mice.

\begin{tabular}{|c|c|c|c|c|c|}
\hline Compound & Ar & Amine & $\mathbf{R}_{1}$ & $\mathbf{R}_{2}$ & $\begin{array}{l}\text { \% Suppression } \\
\text { of parasitemia }\end{array}$ \\
\hline 22 & & & $\mathrm{CF}_{3}$ & $\mathrm{NO}_{2}$ & $98 \pm 1$ \\
\hline 23 & & & $\mathrm{H}$ & F & $73 \pm 16$ \\
\hline 24 & & & $\mathrm{CF}_{3}$ & $\mathrm{NO}_{2}$ & $17 \pm 8$ \\
\hline Alsinol & & & $\mathrm{CF}_{3}$ & $\mathrm{NO}_{2}$ & $76 \pm 30$ \\
\hline CQ & & & & & $87 \pm 11$ \\
\hline
\end{tabular}

Compounds were evaluated at an oral dose of $50 \mathrm{mg} / \mathrm{kg}$ x 4 days. CQ: Chloroquine. Adapted from Quiliano et al. ${ }^{8}$

\section{Chemistry}

Alsinol is easily synthesized in 4 steps at a low cost leading to a mixture of enantiomer. ${ }^{8}$ There were no significant potency differences between enantiomers and the racemic mixture against $P$. falciparum F32 Tanzania, chloroquine sensitive strain $\left(\mathrm{F} 32 \mathrm{IC}_{50}=0.5 \mu \mathrm{M}\right)$ (data not shown). Consequently, there is no need to separate the enantiomers to enhance the bioactivity. 
Alsinol has a calculated n-octanol/water partition coefficient (CLOGP $\log (\mathrm{n}$-octanol/water)) of 3.84; when this coefficient is estimated at $\mathrm{pH} 7.4$ (at protonated form (>99\%)) the value diminishes to 1.51 in increasing its hydrophilicity. A hydrophilic compound is normally well absorbed, even if it has a moderate or low permeation rate; problems in the absorption of a drug can derive from a low aqueous solubility since the flow of a molecule, through the intestinal membrane, is proportional to its concentration gradient between the intestinal lumen and the blood. It is noteworthy that the $\log \mathrm{D}(\mathrm{pH} 7.4) / \log \mathrm{P}$ coefficient is 0.39 for Alsinol, which could be used as a measurable approach of hydrophobicity.

In the research and development of new drugs "Lipinski's rule of 5" helps to estimate poor absorption or permeation of a new molecule, that is more probable if there are more than $5 \mathrm{H}$ bond donors, more than $10 \mathrm{H}$-bond acceptors, molecular weight greater than 500 and calculated Log P (CLogP) greater than $5 .{ }^{27}$ A molecule should not violate more than one of Lipinski's considerations for oral administration to be feasible. Also inside the Ghose ${ }^{28}$ "qualifying range" for drug-like molecules, the chance of missing good compounds is less than $20 \%$. Alsinol respects Lipinski’s rules and the Ghose qualifying range, Table 1.

Earlier, our team reported a computational study, performed for the prediction of the ADME profile of Alsinol in order to evaluate its drug likeness, in that, Alsinol exhibited an oral bioavailability of $81 \%(\% \mathrm{ABS})$, considered interesting as an agent for antimalarial therapy. ${ }^{8}$ Alsinol shows less than 10 rotatable bonds estimating a high probability of good oral bioavailability. ${ }^{40}$

In a previous structure-activity relationship we demonstrated that the incorporation of a single fluorine atom in the Ar (hydrophobic) region provided potency and that if the $-\mathrm{F}$ was moved from para to ortho position, it resulted in a drop of the bioactivity. The central amine also influences the activity. This finding is in agreement with the results reported by Molyneaux et al. $^{41}$ that show unsubstituted amines (free $\mathrm{NH}$ ) have significant antiplasmodial activity in resistant strains compared to their substituted analogues. One feasible explanation is that unsubstituted nitrogen $(\mathrm{NH})$ may interact easily with possible targets, as there is a greater 
hydrogen bond capacity.

The arylamino alcohol ( $ß$-amino or $\gamma$-amino alcohol moiety) is the classic antimalarial chemotype present in some antimalarial drugs, including quinine, mefloquine, lumefantrine, and halofantrine. The structural requirements for antiplasmodial activity include an aromatic and amino alcohol portion linked by a carbon chain of two or three atoms in length. ${ }^{42}$ Moreover, it has been shown that mefloquine presents some activity against Babesia, Trypanosoma and also Leishmania. ${ }^{43}$ This is the reason why we also decided to determine the activity of Alsinol against these parasites.

\section{Antimalarial activity}

The in vitro schizontocidal activity of Alsinol has been assessed against chloroquine-sensitive and resistant strains of $P$. falciparum (NF-54/D6 and FCR-3/C235, respectively). Alsinol was as active as the control on the FCR-3 strain $\left(\mathrm{IC}_{50} \mathrm{CQ}=0.13 \mu \mathrm{M}\right)$ while compared to the $\mathrm{C} 235$ strain $\left(\mathrm{IC}_{50} \mathrm{CQ}=0.048 \mu \mathrm{M}\right)$ the activity was two orders of magnitude lower. On synthesized strains $\left(\mathrm{IC}_{50} \mathrm{CQ} \mathrm{NF}-54=0.04 \mu \mathrm{M}, \mathrm{D} 6=0.014 \mu \mathrm{M}\right) \mathrm{IC}_{50}$ of Alsinol was 2 and 1 order of magnitude higher respectively.

The resistance index $\left(\mathrm{IC}_{50}\right.$ resistant strain $/ \mathrm{IC}_{50}$ sensitive strain) was $<1$ against $\mathrm{NF}-54$, i.e., Alsinol was more active against the resistant strain than against chloroquine-sensitive strains NF-54, showing a typical "mefloquine behavior". ${ }^{6}$ The index was $\geq 1$ against D6, i.e., Alsinol being as or less active against resistant strains (Table 4).

Table 4. Resistance index of Alsinol against multidrug-resistant and chloroquine sensible strains.

\begin{tabular}{|l|l|l|l|}
\hline Strain & IC $_{\mathbf{5 0}} \boldsymbol{\mu M}$ & NF-54 & D6 \\
\hline IC $_{\mathbf{5 0}} \boldsymbol{\mu M}$ & & 1.3 & 0.49 \\
\hline FCR-3 & 0.48 & 0.4 & 1.0 \\
\hline C235 & 1.05 & 0.8 & 2.1 \\
\hline
\end{tabular}


$\mathrm{IC}_{50}$ : growth inhibition of $50 \%$ of parasite. FCR-3 and C235 P. falciparum multidrug-resistant strains. NF-54 and D6 P. falciparum chloroquine sensible strains. Resistance index: $\mathrm{IC}_{50}$ resistant strain / $\mathrm{IC}_{50}$ sensitive strain. Dark cells: calculated data. Clear cells: previously reported data. $^{6,8}$

The gametocyst stages of $P$. falciparum, when mature (10 and 14 days after the first appearance in blood of the asexual forms), are required for transmission of the disease by the mosquito vector. The process leading to the passage of asexual erythrocytic forms to sexual forms is called gametogenesis and represents a transition period in which the parasite is morphologically and biochemically differentiated, preparing the passage to the mosquito.

Although asexual blood forms and immature gametocytes share metabolic profiles (i.e., digestion of hemoglobin), being vulnerable to drugs that act on those metabolic pathways, this situation changes with the mature stages of the gametocytes (stages IV and V) that are relatively insensitive to most current drugs, except primaquine. ${ }^{44}$ In our hands against the gametocyts stages, the reference drug (primaquine) showed activity similar to that reported by Sall et al. ${ }^{45}$ and Chevalley et al., ${ }^{17}$ inhibiting $75 \%$ of gametocytes viability and $100 \%$ of gametocytogenesis at $22 \mu \mathrm{M}$. Alsinol inhibited $50 \%$ of gametocyte viability and gametocytogenesis at $1.23 \mu \mathrm{M}$ and $3.75 \mu \mathrm{M}$ respectively. Figure 3 shows clearly that Alsinol is in the range of activity of primaquine. This remarkable biological activity of Alsinol makes it a potential tool for the control and elimination of malaria, capable of eliminating sexual forms of the parasite, thus blocking the disease transmission cycle. ${ }^{3}$

Working with potential metabolites, ${ }^{8}$ we deduced that antimalarial activity of Alsinol was related to the entire molecule and not to the amine scaffold intermediate.

The in vivo assessment of the blood schizontocidal activity showed dose-dependent behavior of Alsinol against $P$. berghei (Figure 5). In a previous report, Alsinol at $10 \mathrm{mg} / \mathrm{kg} / \mathrm{day}$ inhibited $35 \%$ of parasite growth, ${ }^{6}$ while in another study it inhibited $76 \%$ of parasite growth at $50 \mathrm{mg} / \mathrm{kg} / \mathrm{day} .{ }^{8}$ In our hands Alsinol inhibited $26 \%$ and $100 \%$ of parasite growth at 12.5 
and $50 \mathrm{mg} / \mathrm{kg} /$ day respectively. We showed here that it had an $\mathrm{ED}_{50}(17.4 \mathrm{mg} / \mathrm{kg} / \mathrm{day})$ around 7 times higher than CQ $(2.4 \mathrm{mg} / \mathrm{kg} /$ day $)$, with a highly promising ASN in a very demanding preclinical animal model of infection and using an oral route as the way of administration. This condition involves not only the biological inherent response of a complete organism but also the pharmacokinetics challenges to be overcome by a drug that can be administered in the most recommended way for clinical use. All these experiments were conducted with different product batches, demonstrating correlation in the biological activity of different batches of synthesis of the molecule evidencing reproducibility in the process of obtaining ASN.

In an attempt to get further insight on the mechanism of actions, Alsinol was tested on the hemozoin formation drug target pathway, against plasmepsin ${ }^{8}$ and Hsp90 chaperone. Alsinol was ineffective against all these targets. Alsinol exhibits a mechanism of action different from classical amino alcohols. ${ }^{9}$

\section{Anti-Babesia activity}

Babesia is a tick-borne disease affecting many species of vertebrates, including humans, but it is mostly known because of its role in economic losses in cattle due to decreased milk or meat production, abortions and mortality. The disease causes huge economic losses in cattle, especially in Latin America where it is claimed to reach US 1,365 million/ year. ${ }^{46-48}$

The disease cycle takes place in red blood cells in vertebrate hosts, like Plasmodium. Consequently, peripheral smears of babesiosis can be easily confused with the malaria parasite and mistreated. The human infection causes mild malaria-like fever, but it could be life-threatening in immune-compromised people and people receiving blood transfusion. Its importance in humans has been reported due to the rapid increase in case reports worldwide. ${ }^{49,50}$ Nevertheless, as the disease is unknown to many clinicians, there is certainly high under-reporting of the number of cases. 
The drugs of choice for the treatment of animal babesiosis are imidocarb dipropionate and diminazene acetate, but the latter was withdrawn from the market in Japan and its use is not approved by the U.S. Food and Drug Administration, due to its high toxicity. ${ }^{51}$ The usefulness of antimalarial drugs against different protozoan parasites is currently the subject of intense research. $^{52}$ In vitro artesunate (AS), pyrimethamine and pamaquine completely inhibit the growth of Babesia equi (now T. equi) and B. caballi. ${ }^{53,54}$ Interestingly, it has been shown that artemisone inhibits parasitic growth, reduces clinical symptoms and promotes the recovery of cattle infected with $B$. bovis and B. bigemina without complete elimination of the parasite, which is a desirable effect as it allows animals to develop relative immunity by pre-munition reducing the severity of the disease from future infections. ${ }^{55}$ Artesunate inhibits the parasitic growth of B. bovis and B. gibsoni and does not allow re-emergence upon withdrawal of treatment. ${ }^{51}$ Artemisone inhibits the parasitic growth of $B$. bovis and B. bigemina, B. bigemina being more sensitive to its pharmacological action. ${ }^{55}$ Chloroquine showed a more potent babecidal activity against $B$. divergensis than diminazene acetate ${ }^{56}$ In vivo, artesunate, atovaquone and primaquine inhibited parasitic growth in B. microti-infected mice, without complete elimination of parasites and without producing side effects in experimental animals. ${ }^{51,57}$ Yokoyama et al., ${ }^{58}$ showed that Babesia was sensitive to mefloquine in vitro with $\mathrm{IC}_{50}$ ranging from $4 \mu \mathrm{M}$ to $60 \mu \mathrm{M}$ according to the species used. It was also active against $B$. microti in mice at $5 \mathrm{mg} / \mathrm{Kg}$ by IP route. It is interesting to note that other authors also showed that sensitivity to drugs varies according to strains and species. ${ }^{59,60}$

Human disease is treated with a combination of quinine + clindamycin or atovaquone + azithromycin (and in some extreme cases exchange transfusion) with frequent adverse effects and recent reports of treatment resistance. ${ }^{61}$

In our hands in vitro Alsinol had an $\mathrm{IC}_{50} 10$ times higher than the control drug Imidocarb dipropionate. Interestingly it had an $\mathrm{IC}_{90}$ only 3 times greater than imidocarb, showing promissory activity against the most pathogenic agent of human and bovine babesiosis, Table 2, Figure. 4. 


\section{Anti-Trypanosoma activity}

African trypanosomiasis is a parasitic disease affecting humans and other animals in 36 subSaharan African countries. It is a vector-borne parasitic disease transmitted by tse-tse flies and caused, in humans, by Trypanosoma brucei gambiense (west Africa) and T. brucei rhodesiense (eastern and southern Africa). The human form is commonly known as 'sleeping sickness'.

In sub-Saharan Africa T. congolense, vivax and brucei brucei are responsible for the most important vector-borne livestock disease with dramatic impact on nutritional security ${ }^{62}$. The drugs available for African sleeping sickness are pentamidine isethionate, suramin, melarsoprol, eflornithine, or nifurtimox-eflornithine combination treatment. The currently available trypanocidal drugs are associated with side effects, and the parasites are continually developing resistance. Interestingly Otigbuo and Onabanjo ${ }^{63}$ showed that mefloquine was able to inhibit the multiplication of the parasites in vitro but was also able to clear infected mice after administration of $0.03 \mathrm{mg} / \mathrm{kg}$ for 4 consecutive days. Nevertheless, to the best of our knowledge, mefloquine has not been prescribed for humans so far. Only 3 molecules are available in veterinarian medicine (diminazene diaceturate, isometamidium chloride hydrochloride, homidium). Resistance has been documented ${ }^{64,65}$ due to low quality and inadequate uses. In our hands, Alsinol was able to inhibit parasite growth in vitro but unfortunately, not in vivo.

\section{Leishmanicidal activity}

The leishmaniases are a group of zoonotic diseases caused by protozoa of the genus Leishmania transmitted to humans by phlebotomine sandflies. In humans when inoculated by the vector, promastigotes are rapidly transformed into amastigotes, which actively divide 
within the mononuclear phagocytes of the vertebrate host. More than 300 million people are living in endemic tropical and subtropical areas, 2 million are infected and 30,000 die annually, mainly among the poorest, malnourished part of the population with limited access to health services. Three clinical forms have been described: cutaneous leishmaniasis, mucocutaneous leishmaniasis, and visceral leishmaniasis.

Current anti-leishmanial drugs include pentavalent antimony (the first-choice treatment for both visceral and cutaneous leishmaniasis), amphotericin B and pentamidine (second-line antileishmanial drugs), paromomycin and miltefosine. They have all dramatic toxic effects on liver, heart and kidney, and are also responsible for a long list of side effects (anaemia, fever, anorexia, vomiting, nausea, abdominal pain, malaise, myalgia, arthralgia). Therefore, usage is limited by their toxicity and adverse reactions. Moreover, some of them require hospital settings and long-term administration, up to one month in the case of visceral leishmaniasis. All these factors contribute to the interruption of treatment, increasing the emergence of resistance to drugs. Many studies have been run with artemisinin and derivatives against Leishmania. Although results obtained in laboratories were positive, they were not consistent for introduction with human therapeutic strategies. Mefloquine has been shown to be effective against promastigotes in axenic cultures and showed an $\mathrm{IC}_{50}$ of $8.4 \pm 0.7 \mu \mathrm{M}$. Besides, mefloquine, chloroquine and hydroxychloroquine were active against intracellular amastigotes in macrophage-infected cultures, with $\mathrm{IC}_{50}$ values of $1.56 \pm 0.19 \mu \mathrm{M}, 0.78 \pm 0.08 \mu \mathrm{M}$ and $0.67 \pm 0.12 \mu \mathrm{M}$, respectively. ${ }^{43}$

In our hands, Alsinol was almost 4 times more active than miltefosine but 66 times less active than amphotericin B on promastigotes of Leishmania (the form found in the vector). On amastigotes it was 2 times less active than miltefosine but more than 130 times less active than amphotericin B.

\section{Toxicity}

Alsinol on HepG-2 had a selectivity index of 22. Moreover, genotoxicity profiles of potential 
metabolites were not considered genotoxic using the SOS/umu test. ${ }^{8}$ Toxicity on Vero cells $\left(\mathrm{CC}_{50} 30 \mu \mathrm{M}\right)$ showed that Alsinol had a Selectivity index of 60 compared with activity on $P$. falciparum (FCR-3 and D6) in vitro, one compared with activity on Babesia divergens in vitro, 15 compared with activity on $L$. infantum promastigotes in vitro and only 3.75 compared with activity on L. infantum amastigotes in vitro.

It was therefore 4 times less toxic than amphotericin B and 130 times less toxic than doxorubicine on macrophage-like cells J774A1. On Vero cells, it was 4 times less toxic than doxorubicine and amphotericin $\mathrm{B}$.

\section{Conclusions}

All of humanity is affected by parasites. Unfortunately, the search for new therapeutic alternatives is not a priority of the Pharmaceutical industry as most affected people live in extreme poverty and cannot afford the price of medicines. The role of public research is then to counterbalance this situation in order to propose antiparasitic drugs that are effective, safe and easy to use at low cost.

The usefulness of antimalarial drugs against different protozoan parasites is currently the subject of intense research.

We showed that Alsinol is a potent antiplasmodial agent against both sexual and asexual stages of $P$. falciparum. The remarkable biological activity of Alsinol makes it a potential tool for the control and elimination of malaria, capable of eliminating sexual forms of the parasite, thus blocking the disease transmission cycle.

Alsinol evidences concordance between the results of in vitro studies, with in vivo valuations in a demanding pharmacological model that involves both the different variables that affect the biological response to an anti-infective agent (non-specific immune response, residual effect) and the pharmacokinetic variables derived from oral administration, the most recommended for clinical use in this group of drugs. 
There is an alarming lack of new promising antimalarial hits and a shortage in the production of affordable drugs worldwide. Therefore it could be expected that Alsinol could satisfy this high demand and be a low cost-efficient alternative to avoid a shortcut to the millions of treatments needed to save lives.

In the same way, babesiosis is causing economic losses in cattle-production systems worldwide. This disease contributes to poverty in Southern countries and also has a huge impact on the North. There is no affordable and effective treatment so far. The economic impact is particularly heavy and can be expressed in terms of mortality, loss of production (weight, milk production, skin), and the cost of control. Our findings also show the promising activity of Alsinol against the most pathogenic agent of human and bovine babesiosis.

Nevertheless, although Alsinol showed some activity against African trypanosomoses, it was ineffective in vivo. This point could be circumvented through suitable galenic formulation but further studies are necessary, including toxicity. It is also important to scale up the production of Alsinol to get sufficient amount of Alsinol for industrial requirements.

\section{Acknowledgments}

We wish to thank Michael Browne for editing the document.

Alsinol is a drug designed thanks to a straight collaboration between UMR152 IRD-UPS and the Universidad de Navarra (Unidad de Investigación y Desarrollo de Medicamentos). It was supported by the Direction de la Valorisation au Sud (DVS) in the frame of the IRD Maturation projects programme. This study was funded by the Departamento Administrativo de Ciencia, Tecnología e Innovación (Colciencias) and the French Ministère des Affaires étrangères et du Développement inter- national (MAEE) through ECOSNORD 2013 program [HERMES- 28693] and the Vicedecanatura de Investigación, Facultad de Ciencias, Universidad Nacional de Colombia. This work was supported by PIUNA Project-University of Navarra and Foundation CAN (grant number: 70391). The authors are grateful to the Institute of Tropical Health (ISTUN) of University of Navarra for the financial support and 
help. They also acknowledge the support of Laboratoire d'Excellence (Labex) Parafrap N8ANR-11-LABX-0024. MH Arias is grateful to Departamento Administrativo de Ciencia, Tecnología e Innovación (Colciencias) for their Ph.D. scholarship (Convocatoria 647, Doctorados Nacionales 2014), M Quiliano is grateful to "Programa Nacional de Innovación para la competitividad y productividad" (Innóvate-Perú) for his $\mathrm{PhD}$ scholarship (grant 065FINCYT-BDE-2014). A Mendoza acknowledges ADA (University of Navarra) for a PhD scholarship. The authors thank MF Richards for critical reading of this manuscript.

\section{Conflicts of interest}

There are no conflicts of interest. 


\section{References}

1. Narula AK, Azad CS, Nainwal LM. New dimensions in the field of antimalarial research against malaria resurgence. Eur J Med Chem. 2019;181:111353.

https://linkinghub.elsevier.com/retrieve/pii/S0223523419304532

2. Tilley L, Straimer J, Gnädig NF, Ralph SA, Fidock DA. Artemisinin Action and Resistance in Plasmodium falciparum. Trends Parasitol. 2016;32(9):682-96. https://linkinghub.elsevier.com/retrieve/pii/S1471492216300733

3. D'Alessandro S, Corbett Y, Ilboudo DP, Misiano P, Dahiya N, Abay SM, et al. Salinomycin and other ionophores as a new class of antimalarial drugs with transmissionblocking activity. Antimicrob Agents Chemother. 2015;59(9):5135-44.

4. el Kouni MH. Potential chemotherapeutic targets in the purine metabolism of parasites. Pharmacol Ther. 2003;99(3):283-309.

5. Zucca M, Savoia D. Current developments in the therapy of protozoan infections. Open Med Chem J. 2011;5:4-10.

6. Mendoza A, Pérez-Silanes S, Quiliano M, Pabón A, Galiano S, González G, et al. Aryl piperazine and pyrrolidine as antimalarial agents. Synthesis and investigation of structureactivity relationships. Exp Parasitol. 2011;128(2):97-103.

7. Quiliano, Aldana I. Quinoxaline and Arylaminoalcohol derivatives as antiplasmodial and leishmanicidal agents: a review of our first ten years in the field. Rev Virtual Quim. 2013;5(6):1120-33.

8. Quiliano M, Mendoza A, Fong KY, Pabón A, Goldfarb NE, Fabing I, et al. Exploring the scope of new arylamino alcohol derivatives: Synthesis, antimalarial evaluation, toxicological studies, and target exploration. Int J Parasitol Drugs Drug Resist. 2016;6(3):184-98.

9. Quiliano M, Pabón A, Moles E, Bonilla-Ramirez L, Fabing I, Fong KY, et al. Structureactivity relationship of new antimalarial 1-aryl-3-susbtituted propanol derivatives: Synthesis, preliminary toxicity profiling, parasite life cycle stage studies, target 
exploration, and targeted delivery. Eur J Med Chem. 2018;152:489-514.

10. Pérez-Silanes S, Berrade L, García-Sánchez R, Mendoza A, Galiano S, Pérez-Solórzano B, et al. New 1-Aryl-3-Substituted Propanol Derivatives as Antimalarial Agents.

Molecules. 2009;14(10):4120-35. http://www.mdpi.com/1420-3049/14/10/4120

11. Alvim-Gaston M, Grese T, Mahoui A, Palkowitz AD, Pineiro-Nunez M, Watson I. Open Innovation Drug Discovery (OIDD): a potential path to novel therapeutic chemical space. Curr Top Med Chem. 2014;14(3):294-303.

12. Bruns RF, Watson IA. Rules for Identifying Potentially Reactive or Promiscuous Compounds. J Med Chem. 2012;55(22):9763-72. https://pubs.acs.org/doi/10.1021/jm301008n

13. Muegge I. Selection criteria for drug-like compounds. Med Res Rev. 2003;23(3):30221. http://doi.wiley.com/10.1002/med.10041

14. Trager W, Jensen JB. Human malaria parasites in continuous culture. Science. 1976;193(4254):673-5.

15. Garavito, G. Etude pharmacologique experimentale de láctivité antipaludique dún cmposé de synthése: le chlorure de methylthioninium: Université Toulose III; 2007. https://tel.archives-ouvertes.fr/tel-00639025/document

16. Ifediba T, Vanderberg JP. Complete in vitro maturation of Plasmodium falciparum gametocytes. Nature. 1981;294(5839):364-6.

17. Chevalley S, Coste A, Lopez A, Pipy B, Valentin A. Flow cytometry for the evaluation of anti-plasmodial activity of drugs on Plasmodium falciparum gametocytes. Malar J. 2010;9:49.

18. Amoah LE, Kakaney C, Kwansa-Bentum B, Kusi KA. Activity of Herbal Medicines on Plasmodium falciparum Gametocytes: Implications for Malaria Transmission in Ghana. PloS One. 2015;10(11):e0142587.

19. Gorenflot A, Brasseur P, Precigout E, L'Hostis M, Marchand A, Schrevel J. Cytological and immunological responses to Babesia divergens in different hosts: ox, 
gerbil, man. Parasitol Res. 1991;77(1):3-12.

20. Arias MH, Rodríguez YV, Garavito G. Adaptación y optimización de un método de lectura por fluorometría en el modelo farmacológico in vitro de cultivo de Plasmodium falciparum. Rev Colomb Cienc Quím-Farm. 2016;45(1):127-46.

http://www.revistas.unal.edu.co/index.php/rccquifa/article/view/58024

21. Cachet N, Hoakwie F, Bertani S, Bourdy G, Deharo E, Stien D, et al. Antimalarial Activity of Simalikalactone E, a New Quassinoid from Quassia amara L. (Simaroubaceae). Antimicrob Agents Chemother. 2009;53(10):4393-8.

http://aac.asm.org/cgi/doi/10.1128/AAC.00951-09

22. Peters W, Robinson BL. Malaria. En: Zak O, Sande MA, editores. Handbook of animal models of infection: experimental models in antimicrobial chemotherapy. San Diego: Academic Press; 1999. http://site.ebrary.com/id/10251175

23. Garavito, G. Estandarización de dos modelos de actividad antimalárica como herramientas para la evaluación farmacológica de sustancias o extractos de origen vegetal: Universidad Nacional de Colombia; 2003.

24. Fidock DA, Rosenthal PJ, Croft SL, Brun R, Nwaka S. Antimalarial drug discovery: efficacy models for compound screening. Nat Rev Drug Discov. 2004;3(6):509-20.

25. Arias MH, Deharo E, Valentin A, Garavito G. Adaptation and optimization of a fluorescence-based assay for in vivo antimalarial drug screening. Parasitol Res. 2017;116(7):1955-62.

26. Herbert WJ, Lumsden WH. Trypanosoma brucei: a rapid «matching» method for estimating the host's parasitemia. Exp Parasitol. 1976;40(3):427-31.

27. Lipinski CA, Lombardo F, Dominy BW, Feeney PJ. Experimental and computational approaches to estimate solubility and permeability in drug discovery and development settings. Adv Drug Deliv Rev. 2012;64:4-17. https://linkinghub.elsevier.com/retrieve/pii/S0169409X12002797

28. Ghose AK, Viswanadhan VN, Wendoloski JJ. A Knowledge-Based Approach in 
Designing Combinatorial or Medicinal Chemistry Libraries for Drug Discovery. 1. A

Qualitative and Quantitative Characterization of Known Drug Databases. J Comb Chem. 1999;1(1):55-68. https://pubs.acs.org/doi/10.1021/cc9800071

29. Rodríguez YV, Arias MH, García JO, Deharo E, Garavito G. Pharmacological activity of Curarea toxicofera in combination with classical antimalarial treatments. J

Ethnopharmacol. 2018;222:288-94.

http://linkinghub.elsevier.com/retrieve/pii/S0378874117346652

30. Baker N, de Koning HP, Mäser P, Horn D. Drug resistance in African trypanosomiasis: the melarsoprol and pentamidine story. Trends Parasitol. 2013;29(3):1108. https://linkinghub.elsevier.com/retrieve/pii/S1471492213000020

31. Frenk J, Gómez-Dantés O, Knaul FM. Globalization and Infectious Diseases. Infect Dis Clin North Am. 2011;25(3):593-9. http://linkinghub.elsevier.com/retrieve/pii/S0891552011000377

32. Marcin C, Monika D, Edward H. Parasitic diseases in humans transmitted by vectors. Ann Parasitol. 2015;(3):137-157. http://www.annalsparasitology.eu/go.live.php/download_default/D686/2015-61-3_137.pdf

33. Organización Panamericana de la Salud (OPS). Enfermedades Infecciosas Desatendidas en las Américas. Organización Panamericana de la Salud; 2016. http://www.paho.org/hq/index.php?option=com_content\&view=article\&id=12406\%3Aneg lected-infectious-diseases-americas-success-stories-innovation-reachneediest $\&$ catid=8876\%3 Apublications \&Itemid=42097\&lang=es.

34. Programa de las Naciones Unidas para el Desarrollo (PNUD). Los Objetivos de Desarrollo Sostenible (ODS). Organización de las Naciones Unidas (ONU); 2016. http://www.undp.org/content/undp/es/home/sustainable-development-goals.html

35. World Health Organization (WHO). World malaria report 2017. Geneva: World Health Organization; 2017 p. 196. www.who.int/malaria

36. Kaneko T. Drugs for neglected diseases: part I. Future Med Chem. 2011;3(10):1235-7. 
https://www.future-science.com/doi/full/10.4155/fmc.11.103

37. Monzote L, Siddiq A. Drug Development to Protozoan Diseases. Open Med Chem J. 2011;5:1-3. https://www.ncbi.nlm.nih.gov/pmc/articles/PMC3103878/

38. World Health Organization (WHO), editor. Working to overcome the global impact of neglected tropical diseases: first WHO report on neglected tropical diseases. Geneva: Department of Reproductive health and Research; 2010. 172 p.

39. Zofou D, Nyasa RB, Nsagha DS, Ntie-Kang F, Meriki HD, Assob JCN, et al. Control of malaria and other vector-borne protozoan diseases in the tropics: enduring challenges despite considerable progress and achievements. Infect Dis Poverty. 2014;3(1):1-14. https://idpjournal.biomedcentral.com/articles/10.1186/2049-9957-3-1

40. Veber DF, Johnson SR, Cheng H-Y, Smith BR, Ward KW, Kopple KD. Molecular properties that influence the oral bioavailability of drug candidates. J Med Chem. 2002;45(12):2615-23.

41. Molyneaux C-A, Krugliak M, Ginsburg H, Chibale K. Arylpiperazines displaying preferential potency against chloroquine-resistant strains of the malaria parasite Plasmodium falciparum. Biochem Pharmacol. 2005;71(1-2):61-8.

42. Bhattacharjee AK, Karle JM. Molecular electronic properties of a series of 4quinolinecarbinolamines define antimalarial activity profile. J Med Chem. 1996;39(23):4622-9.

43. Rocha VPC, Nonato FR, Guimarães ET, Rodrigues de Freitas LA, Soares MBP. Activity of antimalarial drugs in vitro and in a murine model of cutaneous leishmaniasis. $\mathbf{J}$ Med Microbiol. 2013;62(Pt 7):1001-10.

44. Butterworth AS, Skinner-Adams TS, Gardiner DL, Trenholme KR. Plasmodium falciparum gametocytes: with a view to a kill. Parasitology. 2013;140(14):1718-34.

45. Sall C, Yapi A-D, Desbois N, Chevalley S, Chezal J-M, Tan K, et al. Design, synthesis, and biological activities of conformationally restricted analogs of primaquine with a 1,10-phenanthroline framework. Bioorg Med Chem Lett. 2008;18(16):4666-9. 
46. Montenegro-James S. Prevalence and control of babesiosis in the Americas. Mem Inst Oswaldo Cruz. 1992;87 Suppl 3:27-36.

47. Rożej-Bielicka W, Stypułkowska-Misiurewicz H, Gołąb E. Human babesiosis. Przeg1 Epidemiol. 2015;69(3):489-94, 605-8.

48. Yabsley MJ, Shock BC. Natural history of Zoonotic Babesia: Role of wildlife reservoirs. Int J Parasitol Parasites Wildl. 2013;2:18-31.

49. Homer MJ, Aguilar-Delfin I, Telford SR, Krause PJ, Persing DH. Babesiosis. Clin Microbiol Rev. 2000;13(3):451-69.

50. Meléndez RD. Babesiosis: una zoonosis emergente en regiones templadas y tropicales. Una revisión. Rev Científica FCV-LUZ. 2000;X(1):13-8.

51. Goo Y-K, Terkawi MA, Jia H, Aboge GO, Ooka H, Nelson B, et al. Artesunate, a potential drug for treatment of Babesia infection. Parasitol Int. 2010;59(3):481-6.

52. Loo CSN, Lam NSK, Yu D, Su X-Z, Lu F. Artemisinin and its derivatives in treating protozoan infections beyond malaria. Pharmacol Res. 2017;117:192-217.

53. Mehlhorn H, Schein E. Redescription of Babesia equi Laveran, 1901 as Theileria equi Mehlhorn, Schein 1998. Parasitol Res. 1998;84(6):467-75.

54. Nagai A, Yokoyama N, Matsuo T, Bork S, Hirata H, Xuan X, et al. Growth-inhibitory effects of artesunate, pyrimethamine, and pamaquine against Babesia equi and Babesia caballi in in vitro cultures. Antimicrob Agents Chemother. 2003;47(2):800-3.

55. Mazuz ML, Golenser J, Fish L, Haynes RK, Wollkomirsky R, Leibovich B, et al. Artemisone inhibits in vitro and in vivo propagation of Babesia bovis and B. bigemina parasites. Exp Parasitol. 2013;135(4):690-4.

56. Rizk MA, El-Sayed SAE-S, AbouLaila M, Tuvshintulga B, Yokoyama N, Igarashi I. Large-scale drug screening against Babesia divergens parasite using a fluorescence-based high-throughput screening assay. Vet Parasitol. 2016;227:93-7.

57. Yao J-M, Zhang H-B, Liu C-S, Tao Y, Yin M. Inhibitory effects of 19 antiprotozoal drugs and antibiotics on Babesia microti infection in BALB/c mice. J Infect Dev Ctries. 
2015;9(9):1004-10.

58. Yokoyama N, AbouLaila M, Igarashi I, Terkawi MA, Munkhjargal T, Davaasuren B, et al. Inhibitory Effects of Pepstatin A and Mefloquine on the Growth of Babesia Parasites. Am J Trop Med Hyg. 2012;87(4):681-8. http://www.ajtmh.org/content/journals/10.4269/ajtmh.2012.12-0218

59. Brasseur P, Lecoublet S, Kapel N, Favennec L, Ballet JJ. In vitro evaluation of drug susceptibilities of Babesia divergens isolates. Antimicrob Agents Chemother. 1998;42(4):818-20.

60. Rodriguez RI, Trees AJ. In vitro responsiveness of Babesia bovis to imidocarb dipropionate and the selection of a drug-adapted line. Vet Parasitol. 1996;62(1-2):35-41.

61. Vial HJ, Gorenflot A. Chemotherapy against babesiosis. Vet Parasitol. 2006;138(12):147-60.

62. Simo G, Rayaisse JB. Challenges facing the elimination of sleeping sickness in west and central Africa: sustainable control of animal trypanosomiasis as an indispensable approach to achieve the goal. Parasit Vectors. 2015;8(1):640. http://www.parasitesandvectors.com/content/8/1/640

63. Otigbuo IN, Onabanjo AO. The in vitro and in vivo effects of mefloquine on Trypanosoma brucei brucei. J Hyg Epidemiol Microbiol Immunol. 1992;36(2):191-9.

64. Geerts S, Holmes PH. Drug management and parasite resistance in bovine trypanosomiasis in Africa. Rome: FAO; 1998. 31 p. (PAAT technical and scientific series).

65. Maudlin I, Holmes PH, Miles MA, editores. The trypanosomiases. Wallingford, UK ; Cambridge, MA, USA: CABI Pub; 2004. 431-444 p. 